\title{
Topics In Finance Part I-Introduction And Stockholder Wealth Maximization
}

Judy Laux, Colorado College, USA

\begin{abstract}
The following article represents the first in a series dedicated to presenting students the opportunity to better understand the key theoretical constructs in the introductory financial management course. The current essay offers an introduction to the series and covers the topics of stockholder wealth maximization and its close cousin, agency theory.
\end{abstract}

Keywords: stockholder wealth maximization, agency theory, financial management

\section{INTRODUCTION}

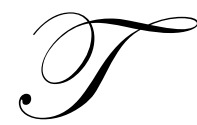

his series of essays is intended to give students in the beginning corporate finance course the opportunity to read about and reflect on some of the major theoretical constructs upon which that course is based. Students often become overwhelmed with the details of the introductory finance course and fail to see the more critical overarching themes that pervade the subject. By providing short essays designed to supplement the managerial finance course, this series attempts to remedy that situation. Topics will include financial analysis, leverage, security valuation, capital structure, capital budgeting, dividend policy, mergers and acquisitions, and working capital management. The series begins with the concepts of stockholder wealth maximization (SWM) and agency theory, because each of the remaining topics relies on the SWM assumption yet offers challenges to managers as agents of the shareholders, covered under the rubric of agency theory. A theoretical section lays the foundation and is followed by an overview of how SWM should apply to some of the decisions the financial manager commonly faces. Finally, this introduction to the series devotes a section to coverage of some of the major conceptual and empirical studies associated with SWM and agency theory.

\section{THEORETICAL BACKGROUND}

Textbooks promote the theory that stockholder wealth maximization (SWM) represents the overarching goal of the financial manager. While bearing some relationship to Milton Friedman's contention, "There is one and only one social responsibility of business - to use its resources and engage in activities designed to increase its profits so long as it...engages in open and free competition, without deception or fraud" [Friedman, 1962, p. 133], the contemporary stance broadens the definition. Typically textbook authors go to great lengths to present this as a long-run concept and caution students about the negative ramifications of managers' attempting to maximize short-term profit (net income) or earnings per share. In addition, maximizing returns with no consideration of commensurate risk is inappropriate, because investors prefer smooth earnings streams to erratic ones. Furthermore, maximization of stockholder wealth must be accomplished in conjunction with consideration for other stakeholder groups. ${ }^{1}$ Finally, financial managers are to consider cash flows rather than accounting income, and the timing of those cash flows matters. So what is a student to make of all this?

\footnotetext{
${ }^{1}$ Textbooks do little to inform students about the on-going and occasionally hard-edged debate about whether stockholder wealth maximization or stakeholder wellbeing should play the central role, a topic addressed in the final section of the current article. See Smith [2003] for a brief and straightforward summary of this issue.
} 
First of all, in a SWM framework managers should make decisions that preserve long-run shareholder wealth. A common measure of this wealth is the market price of the stock — not just this quarter's or this year's price, but the long-run trajectory of that value relative to that of equally risky investments. This requires the manager to become knowledgeable about the parameters that influence a company's stock price, and theoretical constructs such as risk and return, market efficiency, and expected future cash flows come into play.

Economic theory illustrates that risk and return commonly exhibit a positive relationship. That is, as risk increases, investors demand a higher return, because rational economic participants are risk-averse, preferring less risk to more, and they must be compensated for assuming additional risk. Risk is defined as the variability of potential returns, and the field of statistics offers a variety of measures of dispersion related to this concept. For the purposes of this introductory essay, suffice it to say that, in theory, financial managers generally should attempt to either maximize the return per unit of risk or minimize the risk per unit of return in their effort to help maximize stockholder wealth. This "decision rule" plays a major role throughout this series.

A related concept, efficient markets, assumes that as investors in the marketplace receive information, they appropriately gauge the impact of the news on the variability (riskiness) of future cash flows and alter the price of the security in such a way that the return reflects this assessment. That is, if the news means a firm's future cash flows are less risky, then the price would rise (sending the commensurate required return down), or contrarily, if the news signals increased risk, the price would fall, forcing returns to maintain the positive relationship between risk and return. This series will present models for valuing financial securities, such as stocks and bonds, warning the reader that the valuation process can be impaired when accounting earnings, cash flows, and economic income diverge.

Note that, using the risk-return relationship, market participants assess the appropriate impact of news on a stock's price, and financial managers devote a great deal of effort to making that news positive as much as possible. Transparency and disclosure relate to this endeavor, and the accounting profession is charged with much of the responsibility for guiding disclosure. Managers sometimes face a conflict of interests when they must disclose bad news that will send their firm's stock price into a tailspin. Often this leads to another type of "spin" - putting a positive spin on the announcement in hopes of turning lemons into lemonade. On occasion managers cross the line and create a fiction or, perhaps worse, fail to disclose the situation entirely. The articles in this series will present some well-known incidents when managers were caught in this disclosure nightmare.

As mentioned earlier, the concept of market efficiency accents cash flows rather than accounting returns or economic income. This sometimes puzzles students who have dedicated much time and mental energy to learning the fundamental accounting principles that lead to financial statements, including the income statement with its all-important "bottom line" (net income) and its derivative measure, earnings per share. In addition, we measure economic income and accounting income differently. Accounting professors drill into students that meeting expectations related to quarterly earnings per share dictates market price reaction, and now you are asked in the beginning finance course to jettison that information, as "Cash is King" becomes the new mantra. Actually, accountants hold the predictability of future cash flows as a major goal of financial accounting information (despite the sometimes overly heavy accent on the accrual-based income statement). Financial managers take this one step further and focus on actual valuation models that have cash flows at their very core. These models, which exist for stocks, bonds, and virtually every other liability on the corporate balance sheet, are described in the series. The values of these instruments rely on prospective cash flows and perceived risk, so financial managers recognize it as a primary duty to influence these parameters to maximize shareholder wealth. As they carry out this mission, they often face special challenges. As we move through the various topics in this series, we will explain in more detail just how accounting returns are converted to the cash flow streams deemed paramount to financial managers and how financial theory justifies this transformation.

Financial managers make a wide variety of decisions as they determine the asset composition and capital structure that will best maximize firm value over the long run, and at each juncture they are challenged by the fact that they are working as agents for the stockholders (the principals in the relationship). This separation between ownership and management presents possible conflicts of interest wherein managers might be tempted to place their own personal welfare above that of the stockholders. Several studies support the proposition that agency conflicts result from this separation of ownership and control in addition to the conflicting objectives of owners and managers 
and the information asymmetry that exist [Coase 1937, Jensen and Meckling 1976, and Fama and Jensen 1983 are widely cited examples]. Agency theory addresses this dilemma, the costs associated with its prevention, and the impact on stockholder wealth when those preventive measures fail. Most textbooks treat the topic of agency theory under the category of corporate governance, describing how boards of directors, voting rights and procedures, and stockholder privileges are designed to prevent selfish financial decision making. However, with each topic in this series, you will discover the unique kinds of ethical challenges financial managers face as they attempt, in theory, to maximize return per unit of risk and, thereby, stockholder wealth. In each case, you will also see some of the contractual arrangements typically used to ensure this outcome. These mechanisms are not costless, and analysts employ a cost-benefit analytical approach to assess their effectiveness. The following section offers an overview of the decisions financial managers control and briefly describes how risk and return play a role in determining whether the manager is actually maximizing the wealth of the stockholders.

\section{AN OVERVIEW OF FINANCIAL DECISIONS}

Think of the study of financial management as a walk through the balance sheet and consider the financial manager to have two categories of decisions - those related to asset composition and those related to capital structure. Asset composition accents the left-hand side of the corporate balance sheet and addresses questions such as the following (sub-topics noted parenthetically):

- How much cash, marketable securities, accounts receivable, and inventory do we need? What should be the relative composition of those items? (Working Capital Management)

- $\quad$ How many fixed assets (Property, Plant, and Equipment) do we need? (Operating Leverage)

- $\quad$ In which fixed assets should we invest? (Capital Budgeting; Mergers \& Acquisitions)

Essentially, the manager must determine the mix of assets that will offer the most "bang for the buck"- the highest return per unit of risk (or lowest risk per unit of return). You have learned from your introductory accounting course that assets appear on the balance sheet in order of most to least liquid (closest to cash). The financial manager takes that categorization one step further and recognizes that the more liquid an asset, the less risky it is, and the risk-return relationship outlined above suggests that lower risk will be coupled with lower return. Thus, the financial manager must attempt to manage assets in such a way that stockholders receive the highest return for a given risk level and that investment in low-returning assets is minimized. If markets are efficient, managers and stockholders will be rewarded with a higher stock price over the long run.

Capital structure decisions address the right-hand side of the balance sheet (liabilities and stockholders' equity) and force the financial manager to engage the following kinds of questions:

- What strategies should we employ with our accounts payable and short-term financing? (Working Capital Management)

- How much long-term debt should we have in our capital structure, and what forms should that debt take? (Financial Leverage; Cost of Capital; Bond Valuation; Leases; Financial Markets)

- How much equity should we have in our capital structure, and what forms should it take (common stock, preferred stock, or retained earnings)? (Financial Leverage; Cost of Capital; Stock Valuation; Financial Markets)

- $\quad$ How should we design our dividend policy? (Dividend Policy; Capital Budgeting)

In each case, the risk-return tradeoff plays a role, and based on available information regarding the current economic environment, financial managers must determine the appropriate answer to these questions. Meanwhile, external analysts are making their own judgments about the efficacy of those decisions. They, too, are weighing the risk-return tradeoff, and their collective assessment influences the price of the firm's stock. Therefore, amidst all this activity, financial managers must be cognizant of how the investing public is judging their decisions. This requires knowledge about ratio analysis, accounting choices, approaches to disclosure, and how each affects the valuation of financial securities. Thus, the series devotes coverage to these issues. 
How does the financial manager approach the myriad decisions outlined above? As a starting point, because security valuation lies at the heart of wealth maximization, let's look briefly at two examples-common stock and bonds - and how the respective valuation models offer guidance for the financial manager.

The introductory finance course offers the following theoretical model for common stock:

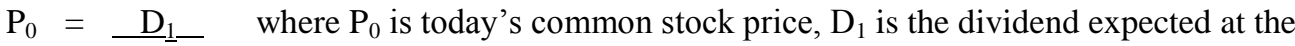 $\mathrm{k}_{\mathrm{e}}-\mathrm{g}$ end of year one, $\mathrm{k}_{\mathrm{e}}$ is the required rate of return for investors, and $\mathrm{g}$ is the growth rate in dividends

While you need not understand the derivation of this model, the mathematical relationships indicate that the financial manager can influence the stock price, $\mathrm{P}_{0}$, in a number of ways, including minimizing $\mathrm{k}_{\mathrm{e}}$, increasing the expected future dividend, $\mathrm{D}_{1}$, or offering a higher growth rate in dividends. Each of these actions possesses ramifications related to risk and return and poses potential agency costs, details discussed in a later article devoted to valuation. flows:

Similarly, bonds are valued by finding the present value of the typical bond's two promised future cash

$$
\begin{gathered}
\mathrm{P}_{\mathrm{b}}=\quad \text { Present value of interest payments (an annuity cash flow stream) } \\
+ \text { Present value of principal at maturity (a one-time cash receipt), } \\
\text { both discounted at the bond buyer's required rate of return }
\end{gathered}
$$

Your knowledge of the time value of money (e.g., that higher discount rates result in lower present values) tells you that one way the financial manager can influence the price of the bonds is by influencing the rate of return required by the bond buyers. This can be accomplished by reducing the perceived riskiness in the eyes of the bond buyer, by achieving a good credit rating, for example. Debt issuance also carries associated risk and return tradeoffs and the potential for agency conflicts. As these topics are addressed in more depth in the current series, you will become familiar with these aspects.

Now that you have some basis for understanding the wealth maximization and agency concepts, we turn to the literature. News headlines, especially scandalous ones, make it imminently clear that financial managers often fail to put shareholder wealth ahead of their personal interests, one reason why agency theory constitutes one of the two major subjects of this introduction. The following section looks at stockholder wealth maximization and agency theory in the literature.

\section{SWM AND AGENCY THEORY IN THE LITERATURE}

Researchers and academics have devoted much time and effort to the study of both stockholder wealth maximization and agency theory, and the current article makes no claim to cover the literature in any depth. The studies reviewed here, however, can be divided into two major categories: Conceptual (theoretical) works and empirical studies. This section briefly addresses each in turn.

In their 1976 article "Theory of the Firm: Managerial Behavior, Agency Costs, and Ownership Structure," Jensen and Meckling set the stage for all subsequent discussions of shareholder wealth maximization and agency theory. In this seminal article, the authors present the contractual view of the firm and the root cause of agency problems - the separation of ownership and control. Managers do not hold the same interests as stockholders, often have access to information shareholders lack, and sometimes make decisions that transfer wealth away from owners. The typical governance arrangement, whereby stockholders elect the Board of Directors (through the vote) who in turn appoint the professional managers of the firm, falls under the category of "corporate governance," and a good deal of literature has been dedicated to the subject.

Shleifer and Vishny [1997] offer a wonderfully comprehensive review of the research on corporate governance up to that time. In addition, they list a number of structures shareholders might put in place to control 
managers' self-interested actions: Long-term incentive contracts; contingent compensation (stock ownership, stock options, threat of dismissal if income is low); institutional ownership (large investors who can exercise control over managers due to significant share ownership); cumulative voting rights; protection by contract; takeover threats; large creditors with substantive debt covenants and rights upon default. Each of these mechanisms involves a cost, however, and economic theory suggests firms will only invest in them up to the point where marginal benefits and costs are equal. Often the challenge is in determining whether such controls are warranted for the firm's specific environment, and news headlines often suggest boards err on the side of laxity and free rein for managers.

The remainder of the conceptual literature covered here looks at stockholder wealth maximization as the guiding purpose for financial management, both how to measure it and whether it is really ethical. The much-cited work "The Stakeholder Theory of the Corporation: Concepts, Evidence, and Implications," by Donaldson and Preston [1995] distinguishes stakeholder from shareholder theory and looks at some of the problems and implications associated with stakeholder theory. The authors look at three aspects of the stakeholder theory (descriptive, instrumental, and normative) and conclude: "the three approaches to stakeholder theory, although quite different, are mutually supportive" (p. 66) and "the ultimate justification for the stakeholder theory is to be found in its normative base" (pp. 87-88). Most importantly, they contend, "the plain truth is that the most prominent alternative to the stakeholder theory (i.e., the 'management serving the shareowners' theory) is morally untenable" [p. 88]. So the more narrow view assumed in most finance textbooks is rejected by these authors.

A number of later conceptual works also question whether SWM is ethical. In their 1996 work "Corporate Ethics and Shareholder Wealth Maximization," Chambers and Lacey argue: "A corporation that embraces SWM does not establish a moral or ethical position but merely acts as a conduit for the ethical beliefs and desires of market participants" (p. 93). This results because investors who value ethics will price ethical considerations and incorporate these preferences into their buy/sell decisions. Dobson [1999] asks whether SWM is amoral, immoral, or moral, and disagrees with Chambers and Lacey that managers "make decisions on the basis of signals received from others through the market mechanism" (p. 71). Rather, by adopting SWM as the objective, managers adopt a certain moral context - utilitarianism (the greatest good for the greatest number, the stockholders) - and their actions are based on "the interests of whoever has the greatest economic influence on the company's stock price" (p. 71). Financial managers "can rely on the market mechanism to translate moral concerns into economic signals. . . [enabling managers] to act on them without contradicting their fiduciary responsibility to stockholders" (p. 74). However, Dobson also contends that SWM "clearly needs tempering"; that is, "managers must use clear moral judgment...in making information available to the public" (p. 74), and transparency becomes paramount. Likewise, Jensen's "Value Maximization, Stakeholder Theory, and the Corporate Objective Function" [2002] promotes "enlightened value maximization," specifying "long-term value maximization....as the firm's objective" (p. 235). Here, the value of the whole firm, including equity, debt, preferred stock, and warrants, is to be maximized, and this requires that good relations be created with all constituencies but that no constituency "can be given full satisfaction if the firm is to flourish and survive" (p. 246). Jensen's perspective moves us from stockholder wealth maximization to stakeholder wealth maximization, a broader vision.

While supporting SWM as a guiding principle, Rappaport [2005] bemoans the use of short-term stock performance to measure wealth, criticizing stock analysts who base stock selections on short-term earnings rather than long-term growth in cash flows: "The biggest roadblock to attaining allocative efficiency is the persistent use of non-DCF models for stock analysis" (p. 67). He argues that, if managers would adopt a long-run view, earnings manipulation would become unnecessary, more profitable projects would be accepted, and discretionary spending on research and development, advertising, maintenance, and hiring would be more appropriate for ensuring the highest long-run value of the firm. While stockholder wealth maximization should guide managerial decisions, risk-adjusted, long-term cash flows are "the essential determinant of value" (p. 72). Danielson et al. [2008] claim that both opponents and proponents of shareholder theory "get it wrong," because the shareholder theory is not aimed at short-term profit maximization at the expense of the long run (p. 62) nor does it direct managers to abuse stakeholders in deference to stockholders. Stakeholder wealth maximization also offers "little guidance about how to balance the often competing interests of various stakeholder groups" (p. 65). In the end, however, the authors stand behind the shareholder model, which balances the competing interests of both current and future stakeholders since a long-run vision is involved. 
Similarly, Madden [2007(a), 2007(b), and 2008] espouses a long-term valuation viewpoint, using a "Shareholder Value Review" [SVR] that relies on the economic concept of competitive corporate life-cycles. By looking at measures of reinvestment, cost of capital, and economic returns, boards could prevent managers from expansions that would reduce the value of the firm and stockholder wealth. The author links this approach with the questionable reporting practices that led to Sarbanes-Oxley: "An SEC mandate of SVRs would motivate managements and boards to become more meaningfully engaged in GAAP improvements with accounting rule-makers and advocates of reform" (p. 102). Many scandalous headlines result when managers use deceptive accounting practices to create the appearance of value. Thus, as with the bulk of these conceptual works, the ethical dimension provides the primary focus.

Although a plethora of empirical research exists, the current article focuses on a few recent articles related to governance and indices associated with measuring governance. A number of studies suggest that, when shareholders have more power relative to management, stocks tend to have relatively higher market values; when managers have fewer protective provisions in place (resulting in greater stockholder rights), this can enhance the value of the stock. In a 2003 study, Gompers, Ishii, and Metrick discovered that "firms with stronger shareholder rights had higher firm value, higher profits, higher sales growth, lower capital expenditures, and made fewer corporate acquisitions" (p. 107). This suggests that stockholder wealth maximization can be accomplished by giving shareholders better control (more "rights"). In this vein, Caton and Goh [2008] hypothesize that, for "democratically governed firms" (those without the six protective provisions specified in earlier works by Gompers et al. [2003, cited above] and Chi [2005]), "the addition of a poison pill may provide currently unprotected managers a high enough level of protection from unwanted, and possibly unwarranted, takeover threats to allow them to focus on long-term value creation" (p. 385). The authors find that only companies with few protective governance structures in place experience significantly positive returns from the addition of this device.

Empiricists have made numerous attempts to produce a "governance index" that measures the relative level of shareholder rights. Bhagat et al. [2008] offers a good review of most indices to date, but the authors caution that "there is no consistent relation between governance indices and measures of corporate performance...no one 'best' measure of corporate governance" (p. 1803). They conclude that "governance indices are highly imperfect instruments for determining how to vote corporate proxies, let alone for making portfolio investment decisions, and ... investors and policymakers should exercise caution in attempting to draw inferences regarding a firm's quality or future stock market performance from its ranking on any particular corporate governance measure" (p. 1803); thus, the jury is still out on the usefulness of these indices.

Finally, Dey [2008] investigates various firm-specific attributes that might indicate the existence of agency conflicts (firm size, organizational complexity, ownership structure, growth, leverage, operating risk, and free cash flows) and finds that governance structures "are positively related to the level of agency conflicts in firms" (p. 1146). Specifically, larger firms, firms with more diffuse ownership structures, firms with higher leverage, and firms with more operating risk have better governance mechanisms in place; thus, governance mechanisms "are a function of the level of agency conflicts in the firm" (p. 1144). Be aware that this section has touched only the surface of the vast amount of literature devoted to stockholder wealth maximization and agency theory. Interested readers are invited to pursue a more comprehensive study. The intention here is to offer a taste of this quite compelling literature.

\section{THIS SERIES CONTINUES}

This introduction provides the foundation for exploring further how stockholder wealth maximization, agency conflicts, risk and return, efficient markets, and cash flows influence the work of the financial manager. In the next article, financial analysis will be investigated from the perspective of the financial manager whose objectives are to outperform the competition and attract capital to the firm.

\section{AUTHOR INFORMATION}

Judy Laux is a Gerald L. Schlessman Professor of Economics and Business at Colorado College. Her research interests include finance and accounting pedagogy and market efficiency. 


\section{REFERENCES}

1. Bhagat, Sanjai; Brian Bolton, and Roberta Romano. 2008. "The Promise and Peril of Corporate Governance Indices." Columbia Law Review, Vol. 108, No. 8: 1803-1869.

2. Caton, Gary L. and Jeremy Goh. 2008. "Corporate Governance, Shareholder Rights, and Shareholder Rights Plans: Poison, Placebo, or Prescription?” Journal of Financial and Quantitative Analysis, Vol. 43, No. 2: $381-400$.

3. Chambers, Donald R. and Nelson J. Lacey. 1996. "Corporate Ethics and Shareholder Wealth Maximization.” Financial Practice and Education, Spring/Summer: 93-96.

4. Chi, Jianxin (Daniel). 2005. "Understanding the Endogeneity Between Firm Value and Shareholder Rights."Financial Management, Vol. 34, Issue 4: 65-76.

5. Coase, Ronald. 1937. "The Nature of the Firm." Economica, Vol. 4, No. 16: 386-405.

6. Danielson, Morris G.; Jean L. Heck, and David R. Shaffer. 2008. "Shareholder Theory—How Opponents and Proponents Both Get It Wrong." Journal of Applied Finance, Fall/Winter: 62-66.

7. Dey, Aiyesha. 2008. "Corporate Governance and Agency Conflicts." Journal of Accounting Research, Vol. 46, Issue 5: 1143-1181.

8. Dobson, John. 1999. "Is Shareholder Wealth Maximization Immoral?" Financial Analysts Journal, September/October: 69-75.

9. Donaldson, Thomas and Lee E. Preston. 1995. "The Stakeholder Theory of the Corporation: Concepts, Evidence, and Implications.” Academy of Management Review, Vol. 20, No. 1: 65-91.

10. Fama, Eugene and Michael Jensen. 1983. "Separation of Ownership and Control." Journal of Law and Economics, Vol. 26: 301-325.

11. Friedman, Milton. 1962. Capitalism and Freedom, Chicago, Illinois: University of Chicago Press.

12. Gompers, Paul; Joy Ishii, and Andre Metrick. 2003. "Corporate Governance and Equity Prices." The Quarterly Journal of Economics, 118: 107-155.

13. Jensen, Michael C. 2002. "Value Maximization, Stakeholder Theory, and the Corporate Objective Function." Business Ethics Quarterly, Vol. 12, Issue 2: 235-256.

14. Jensen, Michael C. and W. H. Meckling. 1976. "Theory of the Firm: Managerial Behavior, Agency Costs and Ownership Structure.” Journal of Financial Economics, 3: 305-360.

15. Madden, Bartley J. 2007(a). "Guidepost to Wealth Creation: Value-Relevant Track Records." Journal of Applied Finance, Fall/Winter: 119-130.

16. 2007(b). "For Better Corporate Governance, The Shareholder Value Review." Journal of Applied Corporate Finance, Vol. 19, No. 1: 102-114.

17. 2008. "Shareholder Value Reviews." Strategic Management, September: 16-20.

18. Rappaport, Alfred. 2005. "The Economics of Short-Term Performance Obsession." Financial Analysts Journal, Vol. 61, No. 3: 65-79.

19. Shleifer, Andrei and Robert W. Vishny. 1997. "A Survey of Corporate Governance." The Journal of Finance, Vol. LII, No. 2: 737-783.

20. Smith, H. Jeff. 2003. "The Shareholders vs. Stakeholders Debate." MIT Sloan Management Review, Summer: $85-90$. 


\section{NOTES}

